\title{
Ursane-Type Triterpenes, Phenolics and Phenolic Derivatives from Globimetula braunii Leaf
}

\author{
Ayodeji Oluwabunmi Oriola 1,*D, Adetunji Joseph Aladesanmi ${ }^{2}$, Thomas Oyebode Idowu ${ }^{3}$, \\ Florence O. Akinwumi ${ }^{4}$, Efere Martins Obuotor ${ }^{5}$, Temilolu Idowu ${ }^{6}$ and Adebola Omowunmi Oyedeji ${ }^{1}$
}

check for

updates

Citation: Oriola, A.O.; Aladesanmi,

A.J.; Idowu, T.O.; Akinwumi, F.O.;

Obuotor, E.M.; Idowu, T.; Oyedeji,

A.O. Ursane-Type Triterpenes,

Phenolics and Phenolic Derivatives

from Globimetula braunii Leaf.

Molecules 2021, 26, 6528. https://

doi.org/10.3390/molecules26216528

Academic Editor: Guy P.P. Kamatou

Received: 7 October 2021

Accepted: 25 October 2021

Published: 28 October 202

Publisher's Note: MDPI stays neutral with regard to jurisdictional claims in published maps and institutional affiliations.

Copyright: (c) 2021 by the authors. Licensee MDPI, Basel, Switzerland. This article is an open access article distributed under the terms and conditions of the Creative Commons Attribution (CC BY) license (https:// creativecommons.org/licenses/by/ $4.0 /)$
1 Department of Chemical and Physical Sciences, Faculty of Natural Sciences, Walter Sisulu University, Mthatha 5099, South Africa; aoyedeji@wsu.ac.za

2 Department of Pharmacognosy, Faculty of Pharmacy, Obafemi Awolowo University, Ile-Ife 220005, Nigeria; jaladesa@yahoo.com

3 Department of Pharmaceutical Chemistry, Faculty of Pharmacy, Obafemi Awolowo University, Ile-Ife 220005 Nigeria; thomasidowu2010@yahoo.com

4 Department of Pharmaceutics, Faculty of Pharmacy, Obafemi Awolowo University, Ile-Ife 220005, Nigeria; fakinwumi@oauife.edu.ng

5 Department of Biochemistry and Molecular Biology, Obafemi Awolowo University, Ile-Ife 220005, Nigeria; efereo@yahoo.com

6 Department of Chemistry, Parkers Building, University of Manitoba, Winnipeg, MB R3T 2N2, Canada; tidowu01@mail.ubc.ca

* Correspondence: aoriola@wsu.ac.za; Tel.: +27-655934742

\begin{abstract}
Globimetula braunii is a hemi-parasitic plant used in African ethnomedicine for the management of microbial infections, rheumatic pain and tumors amongst others. We report the isolation and characterization of eight compounds with their antioxidant and antimicrobial activities. The air-dried powdered leaf was macerated in $\mathrm{EtOH} / \mathrm{H}_{2} \mathrm{O}$ (4:1). The extract was solvent-partitioned into $n$-hexane, EtOAc, $n$ - $\mathrm{BuOH}$ and aqueous fractions. The fractions were screened for their antioxidant properties, using DPPH, FRAP, TAC and FIC assays. Antimicrobial analysis was performed using the micro-broth dilution method. The active EtOAc fraction was purified for its putative compounds on a repeated silica gel column chromatography monitored with TLC-bioautography. The isolated compounds were characterized using spectroscopic methods of UV, FT-IR, NMR and MS. Eight compounds (1-8) were isolated and characterized as 13,27-cycloursane (1), phyllanthone (2), globraunone (3), three phenolics: methyl 3,5-dihydroxy-4-methoxybenzoate (4), methyl 3-methyl4-hydroxybenzoate (5) and guaiacol (6), as well as two phenol derivatives: 4-formaldehyde phenone (7) and 6-methoxy-2H-inden-5-ol (8). The study identified 4 and 6 as natural antioxidant compounds with potential as antimicrobial agents.
\end{abstract}

Keywords: Globimetula braunii; Loranthaceae; ursane-type triterpenes; phenolics; antioxidant; antimicrobial

\section{Introduction}

Globimetula braunii (Engl.) Van Tiegh. (Family Loranthaceae) is a hemi-parasitic and epiphytic plant that derives water and mineral nutrients from its hosts by means of a specialized root system called "haustorium" [1]. It is commonly called "African Mistletoe" and locally called "Afomo Onisano" in Southwest Nigeria [2]. The plant is mostly found on dicot trees, such as Piliostigma thonningii, Leucena leucocephala and Theobroma cacao, where it becomes bushy and woody, growing up to $5 \mathrm{ft}$ in diameter until the host tree withers [3]. At maturity, it produces reddish to reddish brown inflorescence with yellow patches in the form of a match sticks. It is widely distributed across tropical West African countries, such as Nigeria, Ghana, Benin Republic and Cameroun [4].

G. braunii is implicated in the African ethnomedicine for the management of microbial infections, wounds, cholera, hypertension, diabetes, rheumatism, ulcers and tumors $[3,5,6]$. 
Biological studies have shown the antioxidant, antimicrobial and cytotoxic potentials of the leaf extract and its ethyl acetate fraction [7-9]. The hepatic, hematologic, anti-lipidemic, oxytocic, anti-hyperglycemic and anti-cancer activities of the plant's alcoholic, aqueous and ethyl acetate extracts have also been reported [5,6,10-12] with a paucity of information on its chemistry. Preliminary phytochemical reports showed that the plant contained phenolics, terpenes, flavonoids and sterols, while compounds, such as globrauneine AF, lupeol, lupeol palmitate, $\beta$-sitosterol, friedelin, octanoic acid, lactones and flavonoids (quercetin, quercitrin, catechin, rutin and avicularin) have been reported in the plant $[13,14]$.

We report, for the first time, the bioactivity-guided isolation and characterization of three ursane-type triterpenes, three phenolics and two phenol derivatives from the leaf of G. braunii along with their antioxidant and antimicrobial activities.

\section{Results and Discussion}

\subsection{Spectra Data}

Compound 1 (21 mg): 13,27-cycloursane, isolated as white amorphous powder, m.p. 151-152 ${ }^{\circ} \mathrm{C}$; ESI-MS: [M] ${ }^{+}$at $m / z$ 410.0, consistent with the molecular formula $\mathrm{C}_{30} \mathrm{H}_{50}$ $\left[\mathrm{M}-\mathrm{C}_{23} \mathrm{H}_{29}\right]^{+}$at $m / z$ 105.3; ${ }^{1} \mathrm{H}-\mathrm{NMR}\left(300 \mathrm{MHz}, \mathrm{CDCl}_{3}\right) \delta \mathrm{ppm}: 0.75(3 \mathrm{H}, \mathrm{s}, \mathrm{H}-28), 0.89$ $(3 \mathrm{H}, d, J=6.0 \mathrm{~Hz}, \mathrm{H}-30), 0.98(3 \mathrm{H}, s, \mathrm{H}-26), 1.03(3 \mathrm{H}, d, J=3.0 \mathrm{~Hz}, \mathrm{H}-29), 1.07$ (3H, s, H-25), $1.20(3 \mathrm{H}, s, \mathrm{H}-24), 1.28$ (3H, s, H-23); ${ }^{13} \mathrm{C}-\mathrm{NMR}$ (75 MHz, $\left.\mathrm{CDCl}_{3}\right) \delta$ ppm: 39.27 (C-1), 22.30 (C-2), 29.71 (C-3), 30.02 (C-4), 59.51 (C-5), 18.26 (C-6), 41.32 (C-7), 39.72 (C-8), 58.25 (C-9), 37.47 (C-10), 30.52 (C-11), 41.55 (C-12), 38.32 (C-13), 42.16 (C-14), 36.03 (C-15), 32.46 (C-16), 53.12 (C-17), 28.19 (C-18), 42.82 (C-19), 35.04 (C-20), 35.65 (C-21), 32.80 (C-22), 32.11 (C-23), 31.80 (C-24), 20.27 (C-25), 17.96 (C-26), 35.36 (C-27), 14.68 (C-28), 18.68 (C-29), 6.84 (C-30).

Compound 2 (20 mg): 13,27-cycloursan-3-one (Phyllanthone) isolated as white amorphous powder, m.p. $154-155^{\circ} \mathrm{C}$; ESI-MS: $[\mathrm{M}]^{+}$at $m / z 424.3$ consistent with the molecular formula $\mathrm{C}_{30} \mathrm{H}_{48} \mathrm{O}$, [M $\left.-\mathrm{CH}_{2}\right]^{+}$at $m / z$ 410.0, [M $\left.-\mathrm{C}_{23} \mathrm{H}_{29}\right]+$ at $m / z$ 105.3; $\mathrm{UV}\left(\mathrm{CHCl}_{3}\right)$ $\lambda$ max: $270.50 \mathrm{~nm}$; IR (KBr) vmax cm ${ }^{-1}$ : 2948.3 (SP $\left.{ }^{3} \mathrm{C}-\mathrm{H}\right), 2836.5\left(\mathrm{SP}^{3} \mathrm{C}-\mathrm{H}\right), 1681.0(\mathrm{C}=\mathrm{O}$ of ketone); ${ }^{1} \mathrm{H}-\mathrm{NMR}\left(300 \mathrm{MHz}, \mathrm{CDCl}_{3}\right) \delta \mathrm{ppm}: 0.75(3 \mathrm{H}, s, \mathrm{H}-28), 0.89(3 \mathrm{H}, d, J=6.0 \mathrm{~Hz}$, H-30), 0.98 (3H, s, H-26), 1.03 (3H, d, J = 3.0 Hz, H-29), 1.07 (3H, s, H-25), 1.20 (3H, s, H-24), $1.28(3 \mathrm{H}, \mathrm{s}, \mathrm{H}-23) ;{ }^{13} \mathrm{C}-\mathrm{NMR}\left(75 \mathrm{MHz}, \mathrm{CDCl}_{3}\right) \delta \mathrm{ppm}: 39.27$ (C-1), 22.30 (C-2), 213.18 (C-3), 30.02 (C-4), 59.51 (C-5), 18.26 (C-6), 41.32 (C-7), 39.72 (C-8), 58.25 (C-9), 37.47 (C-10), 30.52 (C-11), 41.55 (C-12), 38.32 (C-13), 42.16 (C-14), 36.03 (C-15), 32.46 (C-16), 53.12 (C-17), 28.19 (C-18), 42.82 (C-19), 35.04 (C-20), 35.65 (C-21), 32.80 (C-22), 32.11 (C-23), 31.80 (C-24), 20.27 (C-25), 17.96 (C-26), 35.36 (C-27), 14.68 (C-28), 18.68 (C-29), 6.84 (C-30).

Compound $3(28 \mathrm{mg})$ : Globraunone, isolated as white amorphous powder, m.p. 220-222 ${ }^{\circ} \mathrm{C}$; ESI-MS: $[\mathrm{M}]^{+}$at $m / z$ 554.2, consistent with the molecular formula $\mathrm{C}_{37} \mathrm{H}_{62} \mathrm{O}_{3}$, base peak $\mathrm{M}^{+}$at $m / z 554.2,[\mathrm{M}+\mathrm{H}]^{+}$at $m / z$ 555.0, $\left[\mathrm{M}-\mathrm{CH}_{3}\right]^{+}$at $m / z 539.1,\left[\mathrm{M}-\mathrm{C}_{7} \mathrm{H}_{13} \mathrm{O}_{3}\right]^{+}$ at $m / z$ 409.9, [M $\left.-\mathrm{C}_{14} \mathrm{H}_{25} \mathrm{O}_{3}\right]+$ at $m / z$ 313.6; UV $\left(\mathrm{CHCl}_{3}\right) \lambda \max : 229.00 \mathrm{~nm}, 282.00 \mathrm{~nm}$; IR (KBr) vmax cm ${ }^{-1}$ : $3332.2\left(\mathrm{OH}\right.$, broad), $2974.4\left(\mathrm{SP}^{3} \mathrm{C}-\mathrm{H}\right), 1656.8$ (C=O, weak), 1381.0-1274.7 (C-O). ${ }^{1} \mathrm{H}-\mathrm{NMR}\left(300 \mathrm{MHz}, \mathrm{CDCl}_{3}\right) \delta \mathrm{ppm}: 0.75(3 \mathrm{H}, s, \mathrm{H}-28), 0.89(3 \mathrm{H}, d, J=6.0 \mathrm{~Hz}, \mathrm{H}-30)$, $0.97(3 \mathrm{H}, s, \mathrm{H}-26), 1.02(3 \mathrm{H}, d, J=3.0 \mathrm{~Hz}, \mathrm{H}-29), 1.07(3 \mathrm{H}, s, \mathrm{H}-25), 1.20(3 \mathrm{H}, d, J=3.0 \mathrm{~Hz}$, H-7' , of C-24), 1.28 (3H, s, H-23); ${ }^{13} \mathrm{C}-\mathrm{NMR}\left(75 \mathrm{MHz}, \mathrm{CDCl}_{3}\right) \delta \mathrm{ppm}: 39.27$ (C-1), $22.30(\mathrm{C}-2)$, 213.19 (C-3), 30.02 (C-4), 59.51 (C-5), 18.26 (C-6), 41.32 (C-7), 39.72 (C-8), 58.25 (C-9), 37.47 (C-10), 30.52 (C-11), 41.55 (C-12), 38.32 (C-13), 42.16 (C-14), 36.03 (C-15), 32.46 (C-16), 53.12 (C-17), 28.19 (C-18), 42.82 (C-19), 35.04 (C-20), 35.65 (C-21), 32.80 (C-22), 32.11 (C-23), 20.27 (C-25), 17.96 (C-26), 35.36 (C-27), 14.68 (C-28), 18.68 (C-29), 6.84 (C-30). C-24 Side Chain: $41.74\left(\mathrm{C}-1^{\prime}\right), 72.77\left(\mathrm{C}-2^{\prime}\right), 30.66\left(\mathrm{C}-3^{\prime}\right), 15.80\left(\mathrm{C}-4^{\prime}\right), 35.57\left(\mathrm{C}-5^{\prime}\right), 35.21\left(\mathrm{C}-6^{\prime}\right), 31.80\left(\mathrm{C}-7^{\prime}\right)$.

Compound 4 (1.22 g): methyl 3,5-dihydroxy-4-methoxybenzoate, isolated as ash amorphous powder, m.p. $160-161^{\circ} \mathrm{C}$; ESI-MS: $m / z 198.0[\mathrm{M}]^{+}$consistent with the molecular formula $\mathrm{C}_{9} \mathrm{H}_{10} \mathrm{O}_{5}$, loss of methoxy at $m / z 167.3[\mathrm{M}-31]^{+}, m / z 154.3[\mathrm{M}-44]^{+}$, loss of methyl ethanoate at $m / z 135.2[\mathrm{M}-61]^{+}$, loss of both methoxy and methyl ethanoate at $m / z$ 107.1 [M - 91] $]^{+}$; UV-Vis $(\mathrm{MeOH}) \lambda \max : 210 \mathrm{~nm}, 232 \mathrm{~nm}, 253.0 \mathrm{~nm}$; ${ }^{1} \mathrm{H}-\mathrm{NMR}$ : (300 MHz, MeOD) $\delta$ ppm: 3.85 (3H, s, H-1a), 3.91 (3H, d, J = 3.0 Hz, H-4a), 4.89 (1H, s, H-3, H-5), 7.36 (1H, s, H-2, H-6); ${ }^{13}$ C-NMR: (75 MHz, MeOD) $\delta$ ppm: 55.26 (C-4-methoxy), 
59.72 (C-1-methoxy), 106.80 (C-3, C-5), 125.72 (C-1), 142.41 (C-4), 152.90 (C-2, C-6), 168.05 (C-1-ester).

Compound 5 (26 mg): methyl 3-methyl-4-hydroxybenzoate, isolated as yellow semisolid; ESI-MS: $[\mathrm{M}+\mathrm{H}]^{+}$at $m / z$ 167.7, consistent with the molecular formula $\mathrm{C}_{9} \mathrm{H}_{10} \mathrm{O}_{3}$, base peak $\mathrm{M}^{+}$at $m / z$ 149.2, $[\mathrm{M}-61]^{+}$at $m / z$ 105.2; $\mathrm{UV}-\mathrm{Vis}(\mathrm{MeOH}) \lambda \max : 212.50 \mathrm{~nm}, 242.00$ nm, 266.50 nm; IR (KBr) vmax cm ${ }^{-1}$ : 3385.0 (Phenolic OH, broad), 2939.0 (C-H stretch), 1715.0 ( $\mathrm{C}=\mathrm{O}$, strong), 1586.0 ( $\mathrm{C}=\mathrm{C}$ aromatic), 1336.3-1123.8 (C-O stretch, strong); ${ }^{1} \mathrm{H}-\mathrm{NMR}$ : (300 MHz, MeOD) $\delta$ ppm: $2.05(3 \mathrm{H}, s, \mathrm{Me}), 3.90\left(3 \mathrm{H}, s,-\mathrm{OCH}_{3}\right), 4.88(1 \mathrm{H}, \mathrm{s},-\mathrm{OH}), 6.83$ $\left(1 \mathrm{H}, d,{ }^{3} J=9.0 \mathrm{~Hz}, \mathrm{H}-5\right), 7.21(1 \mathrm{H}, s, \mathrm{H}-2), 7.46(1 \mathrm{H}, d, J=6.0 \mathrm{~Hz}, \mathrm{H}-6) ;{ }^{13} \mathrm{C}-\mathrm{NMR}:(75 \mathrm{MHz}$, MeOD) $\delta$ ppm: 20.35 (C-3, Me), 55.38 (C-1, $\left.-\mathrm{OCH}_{3}\right), 110.74$ (C-2), 114.30 (C-5), 116.27 (C-6), 122.43 (C-1), 144.62 (C-3), 150.09 (C-4), 168.74 (C-1-carbonyl ester).

Compound 6 (29 mg): Guaiacol, isolated as a reddish-brown semisolid, ESI-MS: $\mathrm{m} / z$ $125.1[\mathrm{M}+\mathrm{H}]^{+}$consistent with the molecular formula $\mathrm{C}_{7} \mathrm{H}_{8} \mathrm{O}_{2}$; UV-Vis (MeOH) $\lambda$ max: $214.5 \mathrm{~nm}, 241.5 \mathrm{~nm}, 271.0 \mathrm{~nm}$; IR (KBr) vmax cm${ }^{-1}$ : 3339.7 (Phenolic OH, strong), 1638.2 (C=C aromatic, medium), 1094.0 (C-O, weak); ${ }^{1} \mathrm{H}-\mathrm{NMR}:(300 \mathrm{MHz}, \mathrm{MeOD}) \delta$ ppm: 3.91 $(3 \mathrm{H}, \mathrm{s}, \mathrm{H}-2 \mathrm{a}), 4.87(1 \mathrm{H}, \mathrm{s}, \mathrm{H}-1 \mathrm{a}), 6.73\left(1 \mathrm{H}, d d,{ }^{3} \mathrm{~J}=9.0 \mathrm{~Hz}, \mathrm{H}-3\right), 6.98(1 \mathrm{H}, t, J=3.0 \mathrm{~Hz}, \mathrm{H}-4$, H-5), $7.10(1 \mathrm{H}, t, J=3.0 \mathrm{~Hz}, \mathrm{H}-6) ;{ }^{13} \mathrm{C}-\mathrm{NMR}$ : (75 MHz, MeOD) $\delta$ ppm: 55.34 (C-6a), 102.52 (C-4), 108.17 (C-5), 114.83 (C-3), 129.39 (C-6), 144.55 (C-2), 147.65 (C-1).

Compound 7 (20 mg): 4-methyl-4-formaldehyde phenone, isolated as brown semisolid; ESI-MS: $m / z 136.0[\mathrm{M}]+$ consistent with the molecular formula $\mathrm{C}_{8} \mathrm{H}_{8} \mathrm{O}_{2} ; m / z 119.2$ $[\mathrm{M}-17]^{+}, m / z 106.8[\mathrm{M}-29]^{+}, m / z 104.3[\mathrm{M}-32]^{+}$; UV-Vis (MeOH) $\lambda$ max: $234.5 \mathrm{~nm}$, $254.5 \mathrm{~nm}, 278.50 \mathrm{~nm}, 291.5 \mathrm{~nm}$; IR (KBr) vmax cm ${ }^{-1}$ : 2926.0 (C-H stretch), $1716.4(\mathrm{C}=\mathrm{O})$, 1459.3 (C=C aromatic); ${ }^{1} \mathrm{H}-\mathrm{NMR}:(300 \mathrm{MHz}, \mathrm{MeOD}) \delta \mathrm{ppm}: 1.81(3 \mathrm{H}, \mathrm{s}, \mathrm{H}-1 \mathrm{a}), 7.21(1 \mathrm{H}$, $d, J=3.0 \mathrm{~Hz}, \mathrm{H}-2, \mathrm{H}-6), 7.74(1 \mathrm{H}, d, J=3.0 \mathrm{~Hz}, \mathrm{H}-3, \mathrm{H}-5), 8.48$ (1H, s, H-1b); ${ }^{13} \mathrm{C}-\mathrm{NMR}:$ (75 MHz, MeOD) $\delta$ ppm: 22.29 (C-4b), 54.45 (C-4), 125.56 (C-2, C6), 127.19 (C-3, C-5), 176.60 (C-4a), 199.17 (C-1).

Compound 8 (26 mg): 6-methoxy-2H-inden-5-ol, isolated as yellow semi-solid; ESIMS: $m / z 162.0[\mathrm{M}]+$ consistent with the molecular formula $\mathrm{C}_{10} \mathrm{H}_{10} \mathrm{O}_{2} ;$ loss of $-\mathrm{OH}$ at $m / z$ 145.0 [M - 17]+, loss of $-\mathrm{OCH}_{3}$ at $m / z 131.0$ [M -31$]+, m / z 114.3[\mathrm{M}-48]^{+}$; UV-Vis (MeOH) $\lambda \max : 212 \mathrm{~nm}, 242 \mathrm{~nm}, 266 \mathrm{~nm}$; IR (KBr) vmax cm ${ }^{-1}$ : 3367.6 (Phenolic OH), 2931.6 $\left(\mathrm{SP}^{3}-\mathrm{CH}\right), 1586.0$ (C=C aromatic, stretch), $1468.0(\mathrm{C}=\mathrm{C}$, stretch, 5-member ring), 1336.3 (C-O, of an alcohol), 1213.2 (C-O of an alkoxy); ${ }^{1} \mathrm{H}-\mathrm{NMR}:(300 \mathrm{MHz}, \mathrm{MeOD}) \delta \mathrm{ppm}: 1.31$ (2H, brs, H-1), 3.90 (3H, s, H-6), 4.88 (1H, s, H-5), 7.08 (1H, d, H-4b), 7.21 (1H, t, H-2a, H-2b), 7.46 (1H, dd, H-4a); ${ }^{13} \mathrm{C}-\mathrm{NMR}$ (75 MHz, MeOD) $\delta$ ppm: 29.35 (C-1), 55.24 (C-6'), 104.89 (C-2), 110.77 (C-9), 120.56 (C-3), 116.81 (C-8), 116.23 (C-4), 108.91 (C-7), 144.63 (C-6), 147.63 (C-5).

\subsection{Structure Elucidation}

The ${ }^{13} \mathrm{C}$ NMR spectra of 1 and 2 revealed C-30 compounds, while that of $\mathbf{3}$ showed 37 signals. The DEPT-135 experiment of 1 showed twelve methylene carbons, twelve methyl and methine carbons and six quaternary carbons. That of $\mathbf{2}$ differs from $\mathbf{1}$ by having eleven methylene carbons (one carbon less) attributed to the ketone substituent at $\delta_{C}$ 213.18 ppm. ${ }^{1} \mathrm{H}$ NMR spectra of the three compounds showed seven methyl protons at $\delta_{\mathrm{H}}$ 0.75-1.28 ppm, methylene at $\delta_{\mathrm{H}} 1.50-2.32 \mathrm{ppm}$ and methine at $\delta_{\mathrm{H}} 2.50-3.50 \mathrm{ppm}$. The methyl signals resonated as five singlets and two doublets, which is typical of an $\alpha$-amyrin (ursane-type) of triterpene.

The signal at $\delta_{C} 213.18$ ppm on both the spectra of 2 and 3 confirmed the presence of a ketone. While the $\mathrm{C}=\mathrm{O}$ attachment at the $\mathrm{C}-3$ position was based on the HMBC experiment. Upon consideration of the spectra of 1-3 and in comparison with spectra data on similar compounds reported in the literature, they were identified as 13,27-cycloursane (1), 13,27-cycloursan-3-one previously identified as phyllanthone (2) and hexadecahydro-8-hydroxy-9-(2-hydroxy-6-methylheptyl)-1,2,6a,6b,9,12a-hexamethyl6bHcyclopropa[q]picen-10(11H,12bH,15H)-one (3), named globraunone [15-17]. 
The ${ }^{1} \mathrm{H}$ NMR of 4 showed four signals, which were two aromatic methoxy at $\delta_{\mathrm{H}}$ 3.85 and $3.91 \mathrm{ppm}$, hydroxy at $\delta_{\mathrm{H}} 4.89 \mathrm{ppm}$ and a singlet at $\delta_{\mathrm{H}} 7.36 \mathrm{ppm}$ indicating an aromatic proton. The ${ }^{13} \mathrm{C}$ NMR showed nine signals, indicating a $C_{9}$ compound. The signal at $\delta_{C} 168.05$ ppm indicated a carbonyl ester, two pairs of signals, each at 106.80 for olefinic carbons (C-2/C-6) and $152.90 \mathrm{ppm}$ for phenolic carbons (C-3/C-5), typical of an AABB para-substitution pattern [18]. The IR spectrum further corroborated 4 as a hydroxy benzoate with strong bands at $3367.6 \mathrm{~cm}^{-1}(\mathrm{OH})$ and $1586.0 \mathrm{~cm}^{-1}(\mathrm{R}-\mathrm{O}-\mathrm{C}=\mathrm{O})$. Based on the available spectra data and in comparison, with literature data, 4 was identified as methyl-3,5-dihydroxy-4-methoxybenzoate, previously isolated from Sacoglottis gabonensis stem bark [19].

The ${ }^{1} \mathrm{H}$ NMR of 5 showed three aromatic protons at $\delta_{\mathrm{H}} 6.83,7.21$ and $7.46 \mathrm{ppm}$ : a phenolic $\mathrm{OH}$ at $\delta_{\mathrm{H}} 4.88 \mathrm{ppm}$ and aromatic methoxy at $\delta_{\mathrm{H}} 3.90 \mathrm{ppm}$. A de-shielded methyl group at $\delta_{\mathrm{H}} 2.01 \mathrm{ppm}$ confirmed that it is directly attached to an aromatic ring. There were nine carbon signals on the ${ }^{13} \mathrm{C}$ NMR spectrum. The most de-shielded signal resonated at $\delta_{C} 168.74$. IR spectrum showed having a broad phenolic $\mathrm{OH}$ band at $3385.0 \mathrm{~cm}^{-1}$, a strong carbonyl $\mathrm{C}=\mathrm{O}$ band at $1715.0 \mathrm{~cm}^{-1}, \mathrm{C}=\mathrm{C}$ aromatic band at $1586.0 \mathrm{~cm}^{-1}$ and $\mathrm{C}-\mathrm{O}$ stretching band at 1336.3-1123.8 $\mathrm{cm}^{-1}$. UV absorption at $267 \mathrm{~nm}$ showed the excitation of a benzoate skeleton (tabulated as $268 \mathrm{~nm}$ ). The spectra data of 5 was compared with that of methyl-4-hydroxybenzoate, a bacterial inhibitor previously reported in the bark of Tsuga dumosa [20,21], and it was characterized as methyl-3-methyl-4-hydroxybenzoate.

The ${ }^{13} \mathrm{C}$ NMR spectra of $\mathbf{6}$ showed seven signals. Based on the HSQC experiment, the key functional groups identified include aromatic methoxy at $\delta_{\mathrm{C}} 55.34$ and $\delta_{\mathrm{H}} 3.91 \mathrm{ppm}$, four olefinic protons at $\delta_{\mathrm{H}} 6.73,6.98,7.10$ and $7.20 \mathrm{ppm}$, with carbon signals at $\delta_{\mathrm{C}} 114.83$, $108.17,129.39$ and $110.97 \mathrm{ppm}$, respectively. The NMR data of $\mathbf{6}$ agreed with that of guaiacol reported by Kitanovski et al. [22].

${ }^{1} \mathrm{H}$ NMR of 7 showed a singlet signal at $\delta_{\mathrm{H}} 8.48$ representing an aldehyde carbonyl, two olefinic protons at 7.21 and $7.74 \mathrm{ppm}$, typical of an $\mathrm{A}_{2} \mathrm{~B}_{2}$ para-substitution pattern and a singlet at $1.82 \mathrm{ppm}$. The aldehydic $\left(1716.4 \mathrm{~cm}^{-1}\right)$ and olefinic $\left(1459.3 \mathrm{~cm}^{-1}\right)$ bands were prominent on the IR spectrum, while the UV-Vis spectrum showed $\lambda$ max of $254.5 \mathrm{~nm}$, indicative of a benzene nucleus. Based on the comparison of its spectra data with literature data, 7 was identified as 4-methyl-4-formaldehyde phenone [18].

Compound 8 was showed ten signals on the ${ }^{13} \mathrm{C}$ NMR as a C-10, characterized as $\delta_{C} 55.24$ (methoxy), one methylene carbon at $\delta_{C} 29.35$, four methine carbons at $\delta_{C} 104.89$, $108.91,110.77$ and 116.31 and four quaternary carbons at $\delta_{C} 116.81,120.56,144.63$ and $147.63 \mathrm{ppm}$, based on the DEPT135 experiment. HSQC experiment showed that the carbon signals at $\delta_{\mathrm{C}} 104.89$ and $110.77 \mathrm{ppm}$ were directly attached to the proton signal at $\delta_{\mathrm{H}} 7.21$, while the carbon signals at $\delta_{\mathrm{C}} 116.81$ and $108.91 \mathrm{ppm}$ were directly attached to the protons at $\delta_{\mathrm{H}} 7.46$ and $7.08 \mathrm{ppm}$, respectively, thus, confirming an $\mathrm{AABC}$ ring system [23].

Three ursane-type triterpenes (1-3), three phenolics (4-6) and two phenolic derivatives (7 and 8) were isolated and identified in our study of G. braunii living on Leucena leucocephala (Fabaceae), its host, which marked the first report of these compounds in the plant and the family Loranthaceae. Previous phytochemical studies on the plant have shown the presence of tannins, phenolics, flavonoids, terpenoids and sterols [8,10], while compounds reportedly isolated include lupeol-type triterpenes (globrauneine A-F, lupeol and lupeol acetate), lactones and flavonoids (quercetin, quercitrin, rutin and avicularin), identified in the G. braunii living on Piliostigma thonningi (Fabaceae). Perhaps, this new additions to the repository of compounds in G. braunii might have occurred because of plant-host specificity, which was reported to play a critical role in the quality and quantity of constituents elicited by Mistletoes as well as its influence on their biological properties [4].

Structures of the isolated compounds 1-8 are presented in Figure 1. 


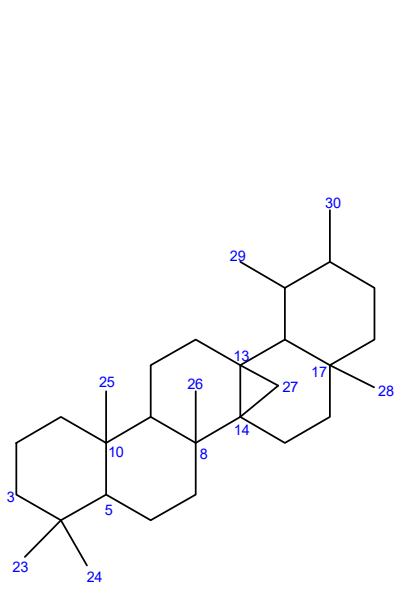

1<smiles>COC(=O)c1cc(O)c(OC)c(O)c1</smiles>

4

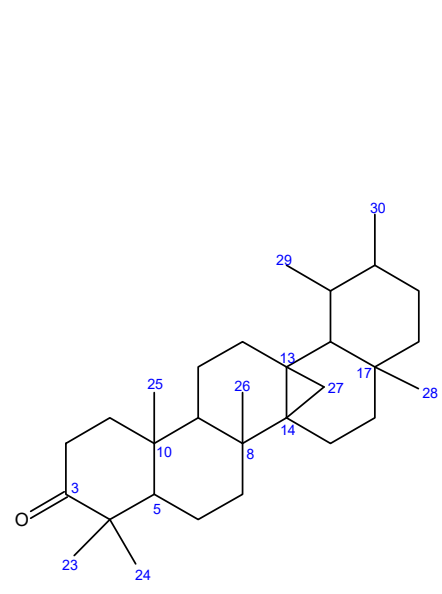

2<smiles>[Y]C([Al])CCCC(O)CC1(C)C(=O)CCC2(C)C1C(O)CC1(C)C2CCC23CC12CCC1(C)CCC(C)C(C)C13</smiles>

3

Figure 1. Structures of isolated compounds from the EtOAc fraction of G. braunii leaves.

\subsection{Evaluation of the Biological Activities of G. braunii Leaves}

TLC-bioautography was used throughout the study. This is a reliable and cost-effective technique to isolate lead compounds by employing a suitable chromatographic process, followed by a biological detection system [24]. The TLC-bioautography antioxidant (DPPH) method was reported to demonstrate an interplay of hydrogen atom transfer (HAT) and single electron transfer, which are important mechanisms in understanding the antioxidant properties of natural products [25]. It was used in this study as a guide for rapid and easy identification and isolation of the free radical scavenging compounds present in the leaf extract of G. braunii. The result presented in Figure 2 showed that fractionation enhanced the antioxidant property of the plant. The EtOAc fraction G, bleached the purple DPPH free radical solution immediately, compared with the $n$-hexane and aqueous fractions, which exhibited a bleaching effect after 5 and $20 \mathrm{~min}$, respectively. The intensity of bleaching (scavenging property) improved with further chromatographic separation.

Quantitative assessments of the antioxidant activity (AOX) of the plant by DPPH, FRAP, TAC and FIC colorimetric assay methods are presented in Table 1. The results showed both concentration-dependent and purification-enhanced increase in the AOX of the plant. The EtOAc fraction exhibited the best AOX among the partition fractions with significant $(p<0.05) \mathrm{IC}_{50}$ values of 8.58 and $154.87 \mu \mathrm{M}$ in the DPPH and FIC assays, respectively. 


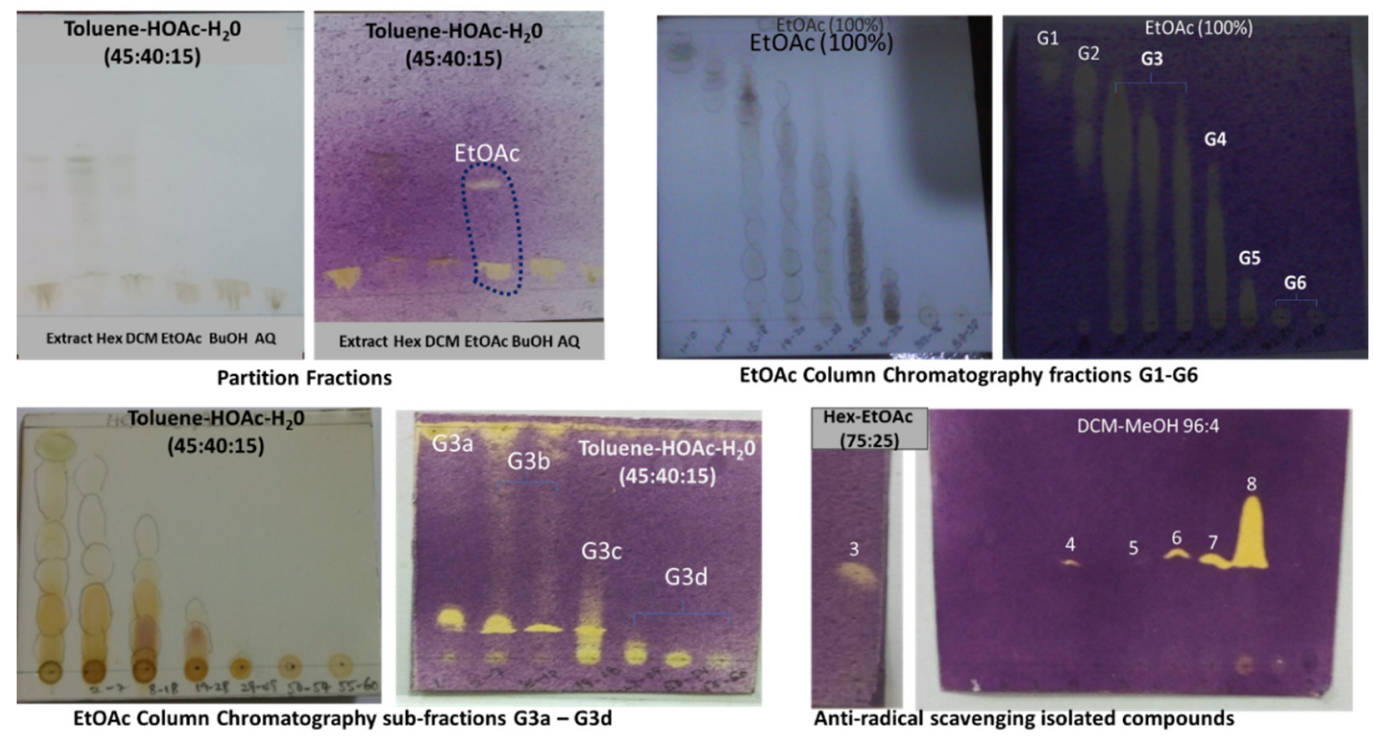

Figure 2. Qualitative antioxidant activity of G. braunii leaves by TLC-bioautography against purple DPPH radical solution. Key: G1-G6: first column bulk fractions, G3a-G3d: second column bulk fractions, 3-8: isolated compounds.

Table 1. Antioxidant activities of G. braunii leaves.

\begin{tabular}{ccccc}
\hline Sample & $\begin{array}{c}\text { DPPH } \\
(\boldsymbol{\mu M})\end{array}$ & $\begin{array}{c}\text { FRAP } \\
(\mathbf{m g A A E} / \mathbf{g})\end{array}$ & $\begin{array}{c}\text { TAC } \\
(\mathbf{m g A A E} / \mathbf{g})\end{array}$ & $\begin{array}{c}\text { FIC } \\
(\boldsymbol{\mu M})\end{array}$ \\
\hline EtOH extract & $31.21 \pm 1.11^{\mathrm{g}}$ & $109.30 \pm 0.76^{\mathrm{c}}$ & $178.15 \pm 3.54^{\mathrm{i}}$ & $281.10 \pm 12.09^{\mathrm{e}}$ \\
$n$-Hexane & $75.89 \pm 5.05^{\mathrm{i}}$ & $172.88 \pm 1.12^{\mathrm{d}}$ & $<10^{\mathrm{a}}$ & $>450^{\mathrm{h}}$ \\
EtOAc & $8.58 \pm 1.39^{\mathrm{c}, * * *}$ & $178.64 \pm 2.04^{\mathrm{f}}$ & $485.81 \pm 50.41^{\mathrm{k}}$ & $154.87 \pm 6.54^{\mathrm{b}}$ \\
$n$-BuOH & $16.06 \pm 0.52^{\mathrm{f}}$ & $175.38 \pm 0.97^{\mathrm{e}}$ & $283.83 \pm 23.01^{\mathrm{j}}$ & $298.79 \pm 32.51^{\mathrm{e}}$ \\
Aqueous & $86.97 \pm 24.74^{\mathrm{j}}$ & $49.94 \pm 18.23^{\mathrm{b}}$ & $<10^{\mathrm{a}}$ & $>450^{\mathrm{h}}$ \\
$\mathbf{1}$ & $>100^{\mathrm{k}}$ & $<10^{\mathrm{a}}$ & $12.02 \pm 1.37^{\mathrm{b}}$ & $>450^{\mathrm{h}}$ \\
$\mathbf{2}$ & $>100^{\mathrm{k}}$ & $347.26 \pm 1.43^{\mathrm{g}}$ & $43.91 \pm 1.20^{\mathrm{c}}$ & $>450^{\mathrm{h}}$ \\
$\mathbf{3}$ & $61.53 \pm 1.01^{\mathrm{h}}$ & $651.77 \pm 7.98^{\mathrm{h}}$ & $77.72 \pm 0.39^{\mathrm{d}}$ & $\geq 450^{\mathrm{h}}$ \\
$\mathbf{4}$ & $6.38 \pm 0.48^{\mathrm{b}, * * *}$ & $702.89 \pm 3.09^{\mathrm{i}}$ & $115.23 \pm 4.12^{\mathrm{f}}$ & $410.64 \pm 8.62^{\mathrm{g}}$ \\
$\mathbf{5}$ & $15.78 \pm 0.41^{\mathrm{e}}$ & $752.76 \pm 13.51^{\mathrm{k}}$ & $121.87 \pm 2.73^{\mathrm{g}}$ & $389.92 \pm 4.76^{\mathrm{f}}$ \\
$\mathbf{6}$ & $0.86 \pm 0.37^{\mathrm{a}, * * *}$ & $720.47 \pm 10.08^{\mathrm{j}}$ & $161.57 \pm 3.79^{\mathrm{h}}$ & $199.63 \pm 5.67^{\mathrm{c}}$ \\
$\mathbf{7}$ & $>100^{\mathrm{k}}$ & $764.09 \pm 10.12^{\mathrm{k}}$ & $81.12 \pm 2.22^{\mathrm{e}}$ & $>450^{\mathrm{h}}$ \\
$\mathbf{8}$ & $70.64 \pm 2.90^{\mathrm{i}}$ & $634.84 \pm 20.31^{\mathrm{h}}$ & $115.76 \pm 3.65^{\mathrm{f}}$ & $255.53 \pm 11.71^{\mathrm{d}}$ \\
Positive control & $11.38 \pm 0.45^{\mathrm{d}}$ & - & - & $13.21 \pm 2.56^{\mathrm{a}}$ \\
\hline
\end{tabular}

$n=3$, values presented as the mean \pm SEM, ${ }^{* * *}$ significant $(p<0.0001)$ compared with positive control. Values with different alphabets in superscript are significantly different at $p<0.05$; isolated compounds (1-8).

The former was significantly $(p<0.05)$ better than $L$-ascorbic acid (AA) with an $\mathrm{IC}_{50}$ value of $11.38 \mu \mathrm{M}$. The power (FRAP) and capacity (TAC) of the EtOAc fraction as an antioxidant were one-sixth and halved, respectively, when compared with AA. This implies that the fraction was able to perform its antioxidant role by hydrogen atom transfer (HAT) to the stable DPPH free radical, single electron transfer (SET) in the FRAP and TAC assays and by metal $\left(\mathrm{Fe}^{2+}\right)$ chelation as in the case of FIC assay $[25,26]$. These findings corroborate the reported in vivo antioxidant activity of the EtOAc fraction in mice [10].

As presented in Table 1, compounds 1-3 had low AOX, while 4-8 were active. The ketone group at C-3 position in phyllanthone 2 might have helped to confer one-third fold FRAP activity, while globraunone 3 proved to be the most active among the terpenes isolated partly due to the presence of ketone and hydroxyl groups. This finding is in consonance with that of Baccouri and Rajhi [27] on the significance of hydroxyl, carbonyl and olefine to the antioxidant activities of compounds as lead molecules for drug discovery. Guaiacol 6 demonstrated the best AOX among the isolated compounds. Its AOX was 
12 times better as a hydrogen-atom-donor (HAT) than AA in the DPPH assay, while, in the FRAP assay, it was 0.76-times as good as a single-electron-donor (SET) when compared with AA.

This could be due to its pi electron-rich benzene ring and hydroxyl group, which can exhibit both HAT and SET mechanisms of antioxidant action. HAT is a one-step reaction by phenolic O-H to effect bond dissociation enthalpy (BDE). SET is a sequential two-step reaction, which entails proton-loss followed by electron-transfer (SPLET), thus, leading to proton affinity (PA) and electron transfer enthalpy (ETE). These mechanisms have been reported to be responsible for the high antioxidant activities of many simple phenolics including phenolic acids [28].

The micro-broth dilution method of microbial susceptibility testing was adopted in the study. It is an objective, high-throughput, cost-effective and quantitative method. It offers high reproducibility, fast generation of MICs, convenience of having pre-prepared panels and the economy of reagents and space that occurs due to the miniaturization of the test, which all make it suitable for the antimicrobial analysis of plant samples. It is also able to assist in generating computerized reports if an automated panel reader is used [29,30].

The antimicrobial activity of the G. braunii as shown in Table 2 showed the EtOAc fraction with the best activity among the fraction, based on its lowest MIC range $(0.63-5.00 \mathrm{mg} / \mathrm{mL})$ and broad-spectrum activity against the test organisms, which justified our focus on the EtOAc fraction. The tested microorganisms were not strongly susceptible to the terpenes (1-3) isolated. Globraunone (3) was only inhibitory against B. subtilis at $2.50 \mathrm{mg} / \mathrm{mL}$ and fairly against $C$. albicans at $5.00 \mathrm{mg} / \mathrm{mL}$. This could be due to the ursanoid ( $\alpha$-amyrin), carbonyl and hydroxyl moieties, all playing key roles in the inhibitory action 3 against $C$. albicans. Similar natural compounds, such as ursolic acid and its derivatives, have been reported to exhibit inhibitory actions against B. subtilis, MRSA, P. aeruginosa and C. albicans at $0.10-0.25 \mathrm{mg} / \mathrm{mL}[31]$.

Table 2. Antimicrobial activities of G. braunii leaves.

\begin{tabular}{|c|c|c|c|c|c|c|c|c|c|c|}
\hline \multirow{3}{*}{ Sample } & \multicolumn{10}{|c|}{ Concentration $(\mathrm{mg} / \mathrm{mL})$} \\
\hline & \multicolumn{2}{|c|}{ E. coli } & \multicolumn{2}{|c|}{$\begin{array}{c}P . \\
\text { aeruginosa }\end{array}$} & \multicolumn{2}{|c|}{$M R S A$} & \multicolumn{2}{|c|}{ B. subtilis } & \multicolumn{2}{|c|}{ C. albicans } \\
\hline & MIC & MBC & MIC & MBC & MIC & MBC & MIC & MBC & MIC & MFC \\
\hline Negative control & - & - & - & - & - & - & - & - & - & - \\
\hline EtOH extract & 20.00 & - & 20.00 & - & 5.00 & 20.00 & 20.00 & - & 10.00 & 20.00 \\
\hline n-Hexane & - & - & - & - & 20.00 & - & - & - & - & - \\
\hline EtOAc & 2.50 & 5.00 & 5.00 & 10.00 & 1.25 & 2.50 & 0.63 & 2.50 & 1.25 & 2.50 \\
\hline$n-\mathrm{BuOH}$ & 5.00 & 20.00 & 2.50 & 10.00 & 2.50 & 5.00 & 5.00 & 20.00 & 1.25 & 2.50 \\
\hline Aqueous & - & - & - & - & - & - & 10.00 & - & 20.00 & - \\
\hline 1 & - & - & - & - & - & - & 20.00 & - & - & - \\
\hline 2 & 20.00 & - & - & - & - & - & 20.00 & - & - & - \\
\hline 3 & 10.00 & 20.00 & 20.00 & - & 20.00 & - & 2.50 & 10.00 & 5.00 & 20.00 \\
\hline 4 & 2.50 & 5.00 & 5.00 & 20.00 & 10.00 & - & 1.25 & 5.00 & 2.50 & 10.00 \\
\hline 5 & 5.00 & 10.00 & 10.00 & - & 20.00 & - & 2.50 & 10.00 & 5.00 & 20.00 \\
\hline 6 & 1.25 & 5.00 & 2.50 & 5.00 & 2.50 & 5.00 & 0.63 & 1.25 & 1.25 & 5.00 \\
\hline 7 & 10.00 & - & 20.00 & - & 20.00 & - & 10.00 & - & 20.00 & - \\
\hline 8 & 2.50 & 5.00 & 5.00 & 20.00 & 2.50 & 5.00 & 2.50 & 5.00 & 5.00 & 10.00 \\
\hline Positive control & & 0.25 & & 0.50 & & 0.50 & & 0.25 & & 0.10 \\
\hline
\end{tabular}

MIC-Minimum Inhibitory Concentration, MBC-Minimum Bactericidal Concentration, MFC-Minimum Fungicidal Concentration; Positive control—Ciprofloxacin (MBC) \& Ketoconazole (MFC); isolated compounds (1-8); negative control $=50 \%$ Aq. $\mathrm{MeOH}$; No activity at $>20 \mathrm{mg} / \mathrm{mL}(-)$.

On the other hand, the phenolic compounds (4-6) and their derivatives (7 and 8) demonstrated remarkable antimicrobial properties. Guaiacol 6, a methoxyphenolexhibited the strongest inhibitory activities against B. subtilis $(0.63 \mathrm{mg} / \mathrm{mL})$ and C. albicans $(1.25 \mathrm{mg} / \mathrm{mL})$ among the compounds. This was closely followed by dihydroxy-4methoxybenzoate (4) with MIC range of 2.50 and $5.00 \mathrm{mg} / \mathrm{mL}$. However, ciprofloxacin and ketoconazole were 2.5- and 12.5- times better antimicrobial agents compared with guaiacol. Based on the observed antimicrobial activities of the isolated compounds, ranking can be 
done as follows: Ketoconazole, Ciprofloxacin $>$ Guaiacol $\mathbf{6}>\mathbf{4}>\mathbf{8}>\mathbf{5}>\mathbf{7}>$ Globraunone $\mathbf{3}$ $>$ Phyllanthone $\mathbf{2}>\mathbf{1}>50 \%$ Aq. $\mathrm{MeOH}$.

Phenolics and its derivatives are referred to as products of the phenylpropanoid pathway, many of which possess significant biological properties. Generally, phenolics with less complex structures (simple phenolics) have been shown to demonstrate remarkable bactericidal and fungicidal activities. These include catechol, caffeic acid, resveratrol and gallic acid amongst others. They all have the phenolic $\mathrm{OH}$ and/or other substituents, such as ester, carboxylic, amine, amide and thiol, which have significant antimicrobial properties [32]. Methyl-4-hydroxybenzoate from the bark of Tsuga dumosa is a known bacterial inhibitor [20,21], while bulbiferate A and B from Microbulbifer spp. are phenolic esters, structurally like compounds 4 and 5 .

According to a report, bulbiferates inhibited the growth of $E$ coli and methicillinsensitive Staphylococcus aureus (MSSA) at $0.20 \mathrm{mg} / \mathrm{mL}$ [33]. In the same vein, the antioxidant and antimicrobial potentials of natural methoxyphenols, such as eugenol, capsaicin and vanillin have been reported. They exhibited an $\mathrm{IC}_{50}$ range of $0.68-1.38 \mathrm{mg} / \mathrm{mL}$ against $S$. aureus, $1.21 \mathrm{mg} / \mathrm{mL}$ (capsaicin) against $P$. aeruginosa and $2.70 \mathrm{mg} / \mathrm{mL}$ (eugenol) against $E$. coli [34].

These leave more to be desired on the biological potentials of natural methoxyphenols and hydroxybenzoates, especially as antioxidant and antimicrobial agents; thus, guaiacol (O-methoxyphenol) (6) and methyl 3,5-dihydroxy-4-methoxybenzoate (4), which were the considerably active antioxidant and antimicrobial compounds identified in this study, could be candidate leads in this respect.

\section{Materials and Methods}

\subsection{Plant Material}

Globimetula braunii was collected during the wet season at the Obafemi Awolowo University (OAU), Ile-Ife Campus, Nigeria (GPS Coordinates: Latitude 7.520767, Longitude 4.530315; DMS Lat $\left.7^{\circ} 31^{\prime} 14.7612^{\prime \prime} \mathrm{N}\right)$. It was found parasitizing Leucena leucocephala (Lam) De Wit. (Family Fabaceae), its host tree. It was authenticated at the Ife Herbarium, OAU, Ile-Ife, where a herbarium specimen was deposited with Voucher number IFE 17229.

\subsection{Plant Extraction and Fractionation}

The leaves of $\mathrm{G}$. braunii were dried at room temperature $\left(25-27^{\circ} \mathrm{C}\right)$. They were powdered $(5.0 \mathrm{~kg})$ and macerated with $25 \mathrm{~L}$ of EtOH- $\mathrm{H}_{2} \mathrm{O}(4: 1)$ at room temperature for $72 \mathrm{~h}$ with frequent agitation. This extraction method was a follow-up process to the previous study on the plant [8]. The filtrate was concentrated to dryness in vacuo on a Heidolph RE 400 Rotary Evaporator set at $45^{\circ} \mathrm{C}$ and $100 \mathrm{rpm}$. The extract $(300 \mathrm{~g})$ was suspended in distilled water $(300 \mathrm{~mL})$ and successively partitioned with $n$-Hexane $(600 \mathrm{~mL} \times 4), \operatorname{EtOAc}(600 \mathrm{~mL} \times 7)$ and $n-\mathrm{BuOH}(300 \mathrm{~mL} \times 2)$.

\subsection{Qualitative Antioxidant Screening}

2,2-Diphenyl-1-picrylhydrazyl (DPPH) Rapid Radical Scavenging Test

Thin-layer chromatography (TLC) bioautography method was used according to Wang et al. [35]. This involved TLC development of the fractions in the appropriate solvent systems in duplicate. The TLC chromatograms were sprayed with $0.5 \mathrm{mg} / \mathrm{mL}$ DPPH in $\mathrm{MeOH}$ and 10\% sulfuric acid. The bleaching effect of the purple DPPH solution by the spots was indicative of the antioxidant potential of the fractions.

\subsection{Quantitative Antioxidant Screening}

All the chemical reagents, solvents and standards used for antioxidant screening were purchased from Sigma Aldrich (St. Louis, MO, USA). 


\subsubsection{DPPH Spectrophotometric Assay}

The DPPH spectrophotometric assay was carried out according to Xiao et al. [36]. A $1 \mathrm{~mL}$ DPPH solution in methanol $(0.05 \mathrm{mg} / \mathrm{mL})$ was added to $1 \mathrm{~mL}$ samples ((positive controls: $L$-ascorbic acid) and (plant fractions/isolated compounds)) at varying concentrations: 50.00, 25.00, 12.50, 6.25 and $3.13 \mu \mathrm{g} / \mathrm{mL}$. The experiment was carried out in triplicate. The samples were incubated in the dark room for $30 \mathrm{~min}$ after which the absorbance was measured at $517 \mathrm{~nm}$ on a CamSpec M 107 Spectrophotometer (Spectronics Camspec Ltd., Leeds, UK), where methanol (negative control) was used as the blank. The percentage inhibition of DPPH by each test sample was calculated thus:

$$
\% \text { Inhibition of sample }=\frac{\mathrm{Abs}_{\text {control }}-\mathrm{Abs}_{\text {sample }}}{\mathrm{Abs}_{\text {control }}} \times 100
$$

where $\mathrm{Abs}_{\text {control }}=$ Absorbance of negative control, $\mathrm{Abs}_{\text {sample }}=$ Absorbance of test sample. The result was expressed as \% inhibition and/or $\mathrm{IC}_{50}$.

\subsubsection{Ferric Reducing Antioxidant Power (FRAP) Assay}

This is based on the reduction of the greenish ferric ion $\left(\mathrm{Fe}^{3+}\right)$ 2,4,6-tri-(2-pyridyl)1,3,5-triazine (TPTZ) to the bluish ferrous ion $\left(\mathrm{Fe}^{2+}\right)$ by natural antioxidants at $593 \mathrm{~nm}$ absorbance measurement. The ferric reducing power of plant extracts were determined as ascorbic acid equivalent (AAE) from the calibration curve of the positive control $(L-$ ascorbic acid) at concentrations 1000.00, 500.00, 250.00, 125.00, 62.50 and $31.25 \mu \mathrm{g} / \mathrm{mL}$ in methanol [37].

\subsubsection{Total Antioxidant Capacity (TAC) Assay}

The TAC assay is based on the reduction of $\mathrm{Mo}^{6+}$ to $\mathrm{Mo}^{5+}$ by the plant samples and subsequent formation of green phosphate/Mo $(\mathrm{V})$ complex at acidic $\mathrm{pH}$ according to Prieto et al. [38]. A $0.3 \mathrm{~mL}$ extract was combined with $3 \mathrm{~mL}$ of reagent solution ( $0.6 \mathrm{M}$ sulfuric acid, $28 \mathrm{mM}$ sodium phosphate and $4 \mathrm{mM}$ ammonium molybdate). The absorbance of the reaction mixture was measured at $695 \mathrm{~nm}$. The calibration curve was prepared by mixing ascorbic (1000.00, 500.00, 250.00, 125.00, 62.50 and $31.25 \mu \mathrm{g} / \mathrm{mL}$ ) with methanol. Data were expressed as mean \pm standard error of mean (SEM). The TAC of each sample was expressed as the number of gram equivalent of ascorbic acid (AAE/g).

\subsubsection{Ferrous Ion Chelating (FIC) Ability}

FIC assay was carried out according to the method of Singh and Rajini [39]. Solutions of $2 \mathrm{mM} \mathrm{FeCl}{ }_{2} \cdot 4 \mathrm{H}_{2} \mathrm{O}$ and $5 \mathrm{mM}$ ferrozine were diluted 20 times. An aliquot $(1 \mathrm{~mL})$ of different concentrations of extract was mixed with $1 \mathrm{~mL} \mathrm{FeCl} 2 \cdot 4 \mathrm{H}_{2} \mathrm{O}$. After 5 min incubation, the reaction was initiated by the addition of ferrozine $(1 \mathrm{~mL})$. The mixture was shaken vigorously, and, after a further 10 min incubation period, the absorbance of the solution was measured spectrophotometrically at $562 \mathrm{~nm}$. The percentage inhibition of ferrozine-Fe ${ }^{2+}$ complex formation was calculated by using the formula:

$$
\% \text { Chelating ability }=\frac{\mathrm{Abs}_{\mathrm{control}}-\mathrm{Abs}_{\text {sample }}}{\mathrm{Abs}_{\mathrm{control}}} \times 100
$$

\subsection{Statistical Analysis}

All quantitative antioxidant data were analyzed using a One-way Analysis of Variance (ANOVA), followed by the Bonferroni post-hoc test on a GraphPad Prism 9 (GraphPad Software Inc., San Diego, CA, USA).

\subsection{Antimicrobial Test}

\section{Micro-Broth Dilution Assay}

The assay was carried according to the Clinical and Laboratory Standard Institute [40,41]. Bacteria and fungi used for the antimicrobial screening were obtained from the culture 
collections of the Microbiology Laboratory of the Department of Pharmaceutics, Obafemi Awolowo University where the experiment was conducted. The bacteria and fungi strains were isolated on a Nutrient broth and Sabouraud Dextrose broth (Merck KGaA, Darmstadt, Germany), respectively. The organisms were identified using their morphological characteristics and standard biochemical tests. The reference strains used were Escherichia coli ATCC 25923, Pseudomonas aeruginosa ATCC 10145, Bacillus subtilis NCTC 8236, methicillin-resistant Staphylococcus aureus ATCC 29213 and Candida albicans ATCC 24433.

Bacteria were maintained on nutrient broth and fungi on Sabouraud Dextrose broth at $4{ }^{\circ} \mathrm{C}$ and sub-cultured regularly. Bacteria were grown for $18 \mathrm{~h}$ in Nutrient broth and culture suspensions of $10^{8} \mathrm{cfu} / \mathrm{mL}$ (equivalent of $0.50 \mathrm{Mc}$ Farland standard) were applied to the dilutions of the fraction/isolates, positive controls (Ciprofloxacin, Ketoconazole) and negative control $50 \%$ aqueous methanol employing a multipoint inoculator. Plates were incubated at $37^{\circ} \mathrm{C}$ for $24 \mathrm{~h}$. for bacteria strains and $25^{\circ} \mathrm{C}$ for $72 \mathrm{~h}$ for fungal strains, after which all plates were observed for growth of the microorganisms. The minimum dilution of fractions completely inhibiting the growth and killing each organism was taken as the $\mathrm{MIC}$ and MBC/MFC. The sample with the lowest range of MIC and the widest spectrum of activity against bacteria and fungi was taken as the most active.

\subsection{Isolation of Compounds \\ Column Chromatography of the EtOAc Fraction}

The EtOAc fraction (G, $30.0 \mathrm{~g})$ was adsorbed unto $30 \mathrm{~g}$ silica gel (70-230 ASTM mesh, Merck KGaA, Darmstadt, Germany), dry-packed on a $600 \mathrm{~g}$ silica gel stationary phase within a $300 \mathrm{~cm} \times 5 \mathrm{~cm}$ glass column (L x i.d., Fisher Scientific, Waltham, MA, USA). Mobile phase comprising solvent systems of increasing polarity was introduced as thus: $n$-Hex $(100 \%, 700 \mathrm{~mL}$, de-gas), EtOAc (9:1, 8:2, . . 1:9; $500 \mathrm{~mL}$ each), EtOAc $(100 \% ; 700 \mathrm{~mL})$, EtOAc-MeOH (95:5, 9:1, 8:2, 1:1; $500 \mathrm{~mL})$ and $\mathrm{MeOH}(100 \% ; 250 \mathrm{~mL})$. Eluates were collected in $20 \mathrm{~mL}$ test tubes (1-303). They were bulked into six sub-fractions G1-G6 based on their TLC profiles $\left(\mathrm{SiO}_{2}\right.$, Hex-EtOAc 75:25, 1:1, EtOAc-MeOH 1:1, UV 254 and 365 nm, 10\% $\mathrm{H}_{2} \mathrm{SO}_{4}$ spray).

After a $24 \mathrm{~h}$ period, sub-fraction G1 (1.2 g) afforded solid deposits a, b and c, while sub-fraction G2 (3.1 g) gave a solid deposit d. Each deposit was washed with $100 \mathrm{~mL}$ of $\mathrm{MeOH}(100 \%)$, affording compounds 1-4, respectively. The most active sub-fraction G3 (3.5 g), based on TLC-bioautography was further purified on a Silica gel column with mobile phase from DCM $(100 \%, 100 \mathrm{~mL})$ to DCM-MeOH $(98: 2,96: 4, \ldots, 80: 20 ; 100 \mathrm{~mL}$ each). The eluates (1-187) were collected in $10 \mathrm{~mL}$ test tubes and were subsequently bulked into four sub-fractions, G3a-G3d, based on their TLC profiles $\left(\mathrm{SiO}_{2}, \mathrm{DCM}-\mathrm{MeOH} 97: 3\right.$, 85:15, 1:1, UV 254 and $365 \mathrm{~nm}, 10 \% \mathrm{H}_{2} \mathrm{SO}_{4}$ spray). A preparative TLC separation of G3c, using DCM-MeOH (96:4) afforded bands i-iv, labelled compounds 5-8.

\subsection{Characterization of Isolated Compounds}

Thin-layer chromatography (TLC) of compounds was performed on aluminumbacked silica gel 60 F254 GF plates (0.25 mm, Merck KGaA, Darmstadt, Germany). Chemical detection of the class of compound isolated was done by spraying the developed TLC plates with chromogenic reagents, such as $5 \% \mathrm{FeCl}_{3}$ for phenolics and $10 \% \mathrm{H}_{2} \mathrm{SO}_{4}$ for terpenes. Melting point ranges of the solid compounds were determined on Gallenkamp MPD350-BM 3.5 electrothermal instrument (Gallenkamp, Kent, UK). The UV-Vis absorption was determined within 200-800 nm on Shimadzu UV-1800 UV/Visible Scanning Spectrophotometer: 115 VAC (Shimadzu Corporation, Nkagyo-Ku, Kyoto, Japan). Infrared spectroscopy was done within the $650-4000 \mathrm{~cm}^{-1}$ transmittance on Cary 630 FTIR Spectrometer (Agilent Technologies Inc., Santa Clara, CA, USA). ${ }^{1} \mathrm{H},{ }^{13} \mathrm{C}$ and $2 \mathrm{D}$ (DEPT135, COSY, HSQC and HMBC) NMR spectra of compounds were recorded as solutions on Bruker AMX-300 Spectrometer (Bruker Corporation, Bremen, Germany), where tetramethylsilane was used as the internal standard. 
Signals were recorded in the order of chemical shifts $(\delta)$ in part per million $(\mathrm{ppm})$ relative to the indicated deuterated solvents $\left(\mathrm{CDCl}_{3}, \mathrm{MeOD}\right)$, integral values (number of protons), multiplicity ( $s$, singlet; $d$, doublet; $t$, triplet; and $m$, multiplet) and coupling constant $(J)$ in hertz (Hz). Electrospray Ionization Mass Spectrometry (ESI-MS) was performed on a Varian 500-MS ion trap Mass Spectrometer (Varian, Inc., Palo Alto, CA, USA) for molecular weight determination, expressed in mass-to-charge ratio $(\mathrm{m} / \mathrm{z})$. ESI-MS analysis was performed at $10 \mu \mathrm{L} / \mathrm{min}$ sample infusion flow rate; $2.56 \mathrm{kV}$ capillary voltage; $3.0 \mathrm{~V}$ extraction cone; $475 \mathrm{~L} / \mathrm{h}$ desolvation-gas flow rate; 80 and $100{ }^{\circ} \mathrm{C}$ for the source- and desolvation-gas temperatures, respectively; and $5.82 \mathrm{~mm}$ Vernier-probe-adjuster position. The spectrometer scan range was $99.5-1500.5 \mathrm{~m} / \mathrm{z}$ in the positive mode.

\section{Conclusions}

Our activity-guided study on the leaves of G. braunii led to isolation of eight compounds (1-8) from the most active EtOAc fraction. The compounds were identified based on their spectroscopic data and in comparison with literature reports. They were ursanetype triterpenes (1-3), phenolics (4-6) and phenolic derivatives (7 and 8), all reported for the first time in the plant and in the family Loranthaceae. Guaiacol (6) and methyl 3,5-dihydroxy-4-methoxybenzoate (4) were remarkably antioxidant with considerable antimicrobial potentials.

Author Contributions: Conceptualization, A.O.O. (Ayodeji Oluwabunmi Oriola) and A.J.A.; methodology, A.O.O. (Ayodeji Oluwabunmi Oriola) and A.J.A.; software, A.O.O. (Ayodeji Oluwabunmi Oriola) and T.I.; validation, A.J.A., T.O.I., E.M.O. and A.O.O. (Adebola Omowunmi Oyedeji); formal analysis, A.O.O. (Ayodeji Oluwabunmi Oriola), E.M.O., F.O.A. and T.I.; investigation, A.O.O. (Ayodeji Oluwabunmi Oriola); resources, A.O.O. (Ayodeji Oluwabunmi Oriola), E.M.O. and A.O.O. (Adebola Omowunmi Oyedeji); data curation, A.O.O. (Ayodeji Oluwabunmi Oriola), E.M.O., F.O.A. and T.O.I.; writing—original draft preparation, A.O.O. (Ayodeji Oluwabunmi Oriola); writing-review and editing, A.J.A. and A.O.O. (Adebola Omowunmi Oyedeji); visualization, A.J.A., T.O.I., E.M.O. and F.O.A.; supervision, A.J.A. and T.O.I.; project administration, A.O.O. (Ayodeji Oluwabunmi Oriola), A.J.A., T.O.I.; funding acquisition, A.O.O. (Ayodeji Oluwabunmi Oriola) and A.O.O. (Adebola Omowunmi Oyedeji). All authors have read and agreed to the published version of the manuscript.

Funding: The study received no funding support.

Institutional Review Board Statement: Not applicable.

Informed Consent Statement: Not applicable.

Data Availability Statement: Not available.

Acknowledgments: The corresponding author acknowledges the Drug Research and Production Unit, O.A.U., Ile-Ife, Nigeria, for study leave permission to Walter Sisulu University, South Africa.

Conflicts of Interest: The authors declare no conflict of interest.

Samples Availability: Samples of the compounds 1-8 are available from the authors.

\section{References}

1. Siegfried Didier, D.; Obiang Nestor Laurier, E.; Din, N.; Richard Jules, P.; Victor, T.; Henri, F.; Georges, S.; Alain Didier, M.; Issaka Joseph, B.; Akoa, A. An Assessment on the Uses of Loranthaceae in Ethno Pharmacology in Cameroon: A Case Study Made in Logbessou, North of Douala. J. Med. Plants Res. 2009, 3, 592-595.

2. Ayoola, M.D.; Oriola, A.O.; Faloye, K.O.; Aladesanmi, A.J. Two Antihyperglycaemic Compounds from Globimetula braunii (Engl.) Van Tiegh (Loranthaceae). GSC Biol. Pharm. Sci. 2020, 2020, 46-054. [CrossRef]

3. Burkill, H.M. The Useful Plants of West Tropical Africa. Available online: https://agris.fao.org/agris-search/search.do?recordID= GB9618106 (accessed on 8 August 2021).

4. Adesina, S.K.; Illoh, H.C.; Johnny, I.I.; Jacobs, I.E. African Mistletoes (Loranthaceae); Ethnopharmacology, Chemistry and Medicinal Values: An Update. Afr. J. Tradit. Complement. Altern. Med. AJTCAM 2013, 10, 161-170. [CrossRef]

5. Okpuzor, J.; Kareem, G.; Ejikeme, C. Lipid Lowering Activity of Globimetula braunii. Res. J. Med. Plant 2009, 3, 45-51. [CrossRef]

6. Okpuzor, J.; Ogbunugafor, H.A.; Kareem, G.K. Hepatic and Hematologic Effects of Fractions of Globimetula braunii in Normal Albino Rats. EXCLI J. 2009, 8, 182-189. 
7. Oriola, A.O.; Aladesanmi, A.J.; Arthur, G. Anticancer Activity of Three African Mistletoes. Niger. J. Nat. Prod. Med. 2018, 22, 129-134. [CrossRef]

8. Oriola, A.O.; Aladesanmi, A.J.; Akinkunmi, E.O.; Olawuni, I.J. Antioxidant and Antimicrobial Studies of Some Hemi-Parasitic West African Plants. Eur. J. Med. Plants 2020, 31, 17-26. [CrossRef]

9. Enehezeyi Aliyu, R.; Alonge, S.; Aliyu, R. Antibacterial Activity of Globimetula braunii Sourced from Five Different Host Trees in Screening Cowpea Magic Rils for Variation in Agro-Physiological Traits for Tolerance to Biotic and Abiotic Stresses View Project Antibacterial Activity of Globimetula braunii Sourced from Five Different Host Trees in Samaru, Zaria, Nigeria. Int. J. Curr. Sci. 2015, 18, 117-123.

10. Okpuzor, J.; Ogbunugafor, H.; Karecm, G.K. Antioxidative Properties of Ethyl Acetate Fraction of Globimetula braunii in Normal Albino Rats. J. Biol. Sci. 2009, 9, 470-475. [CrossRef]

11. Erukainure, O.L.; Abovwe, J.A.; Adefegha, A.S.; Egwuche, R.U.; Fafunso, M.A. Antilipemic and Hypocholesteremic Activities of Globimetula braunii in Rats. Exp. Toxicol. Pathol. 2010, 63, 657-661. [CrossRef]

12. Ie, O.; Zam, N. Oxytocic Properties of the Aqueous Extract of Globimetula braunii (Loranthaceae). Pak. J. Pharm. Sci. 2008, 21, 356-360.

13. Muhammad, K.J.; Jamil, S.; Basar, N.; Bakri Bakar, M.; Sarker, S.D.; Flanagan, K.J.; Senge, M.O. Lactones and Flavonoids Isolated from the Leaves of Globimetula braunii. NPC Nat. Prod. Commun. 2017, 12, 1455-1458.

14. Muhammad, K.J.; Jamil, S.; Basar, N.; Sarker, S.D.; Mohammed, M.G. Globrauneine A-F: Six New Triterpenoid Esters from the Leaves of Globimetula braunii. Nat. Prod. Res. 2019, 34, 2746-2753. [CrossRef] [PubMed]

15. Ren, F.C.; Li, G.Y.; Nama, N.; Liu, Z.H.; Yang, L.; Zhou, J.; Hu, J.M. 13,27-Cycloursane, Ursane and Oleanane Triterpenoids from the Leaves of Lucuma nervosa. Fitoterapia 2019, 136, 104178. [CrossRef] [PubMed]

16. Ndlebe, V.J.; Crouch, N.R.; Mulholland, D.A. Triterpenoids from the African Tree Phyllanthus polyanthus. Phytochem. Lett. 2008, 1, 11-17. [CrossRef]

17. Lee, T.-H.; Juang, S.-H.; Hsu, F.-L.; Wu, C.-Y. Triterpene Acids from the Leaves of Planchonella duclitan (Blanco) Bakhuizan. J. Chin. Chem. Soc. 2005, 52, 1275-1280. [CrossRef]

18. Pavia, D.L.; Lampman, G.M.; Kriz, G.S.; Vyvyan, J.R. Nuclear Magnetic Resonance Spectroscopy Part Five: Advanced NMR Techniques. In Introduction to Spectroscopy; Thomson Learning Inc.: Boston, MA, USA, 2013; pp. 511-576.

19. Alade, G.O.; Moody, J.O.; Awotona, O.R.; Adesanya, S.A.; Lai, D.; Proksch, P. Spermicidal Constituents of Ethanolic Extract of Sacoglottis gabonensis Stem Bark. Folia Med. 2017, 59, 437-442. [CrossRef] [PubMed]

20. MedChemExpress. Methylparaben-Advanced Dermatology. Available online: https://www.advanced-dermatology.com.au/ methylparaben (accessed on 25 September 2021).

21. MedChemExpress. Methyl Paraben (Methyl 4-Hydroxybenzoate) I Bacterial Inhibitor | MedChemExpress. Available online: https://www.medchemexpress.com/Methyl_Paraben.html (accessed on 6 October 2021).

22. Kitanovski, Z.; Cusak, A.; Grgić, I.; Claeys, M. Chemical Characterization of the Main Products Formed through Aqueous-Phase Photonitration of Guaiacol. Atmos. Meas. Tech. 2014, 7, 2457-2470. [CrossRef]

23. Guthrie, R.D. Introduction to Spectroscopy (Pavia, Donald; Lampman, Gary, M.; Kriz, George, S., Jr.). J. Chem. Educ. 1979, 56, A323. [CrossRef]

24. Dewanjee, S.; Gangopadhyay, M.; Bhattacharya, N.; Khanra, R.; Dua, T.K. Bioautography and Its Scope in the Field of Natural Product Chemistry. J. Pharm. Anal. 2015, 5, 75-84. [CrossRef] [PubMed]

25. Santos-Sánchez, N.F.; Salas-Coronado, R.; Villanueva-Cañongo, C.; Hernández-Carlos, B. Antioxidant Compounds and Their Antioxidant Mechanism; IntechOpen: London, UK, 2019. [CrossRef]

26. Siddeeg, A.; AlKehayez, N.M.; Abu-Hiamed, H.A.; Al-Sanea, E.A.; AL-Farga, A.M. Mode of Action and Determination of Antioxidant Activity in the Dietary Sources: An Overview. Saudi J. Biol. Sci. 2021, 28, 1633-1644. [CrossRef]

27. Baccouri, B.; Rajhi, I. Potential Antioxidant Activity of Terpenes. In Terpenes and Terpenoids Recent Advances; Intech Open Book Series; IntechOpen: London, UK, 2021. [CrossRef]

28. Chen, J.; Yang, J.; Ma, L.; Li, J.; Shahzad, N.; Kyung Kim, C.K. Structure-Antioxidant Activity Relationship of Methoxy, Phenolic Hydroxyl, and Carboxylic Acid Groups of Phenolic Acids. Sci. Rep. 2020, 10, 2611. [CrossRef] [PubMed]

29. Chen, S.C.; Liu, J.W.; Wu, X.Z.; Cao, W.L.; Wang, F.; Huang, J.M.; Han, Y.; Zhu, X.Y.; Zhu, B.Y.; Gan, Q.; et al. Comparison of Microdilution Method with Agar Dilution Method for Antibiotic Susceptibility Test of Neisseria gonorrhoeae. Infect. Drug Resist. 2020, 13, 1775-1780. [CrossRef]

30. Reller, L.B.; Weinstein, M.; Jorgensen, J.H.; Ferraro, M.J. Antimicrobial Susceptibility Testing: A Review of General Principles and Contemporary Practices. Clin. Infect. Dis. 2009, 49, 1749-1755. [CrossRef]

31. Jesus, J.A.; Lago, J.H.G.; Laurenti, M.D.; Yamamoto, E.S.; Passero, L.F.D. Antimicrobial Activity of Oleanolic and Ursolic Acids: An Update. Evid.-Based Complement. Altern. Med. 2015, 2015. [CrossRef] [PubMed]

32. Maddox, C.E.; Laur, L.M.; Tian, L. Antibacterial Activity of Phenolic Compounds Against the Phytopathogen Xyllela fastidiosa. Curr. Microbiol. 2010, 60, 53-58. [CrossRef] [PubMed]

33. Jayanetti, D.R.; Braun, D.R.; Barns, K.J.; Rajski, S.R.; Bugni, T.S. Bulbiferates A and B: Antibacterial Acetamidohydroxybenzoates from a Marine Proteobacterium, Microbulbifer sp. J. Nat. Prod. 2019, 82, 1930-1934. [CrossRef]

34. Orlo, E.; Russo, C.; Nugnes, R.; Lavorgna, M.; Isidori, M. Natural Methoxyphenol Compounds: Antimicrobial Activity Against Foodborne Pathogens and Food Spoilage Bacteria, and Roles in Antioxidant Processes. Foods 2021, 10, 1807. [CrossRef] 
35. Wang, J.; Yue, Y.D.; Tang, F.; Sun, J. TLC Screening for Antioxidant Activity of Extracts from Fifteen Bamboo Species and Identification of Antioxidant Flavone Glycosides from Leaves of Bambusa textilis Mcclure. Molecules 2012, 17, 12297-12311. [CrossRef] [PubMed]

36. Xiao, F.; Xu, T.; Lu, B.; Liu, R. Guidelines for Antioxidant Assays for Food Components. Food Front. 2020, 1, 60-69. [CrossRef]

37. Benzie, I.F.F.; Strain, J.J. [2] Ferric Reducing/Antioxidant Power Assay: Direct Measure of Total Antioxidant Activity of Biological Fluids and Modified Version for Simultaneous Measurement of Total Antioxidant Power and Ascorbic Acid Concentration. Methods Enzymol. 1999, 299, 15-27. [CrossRef] [PubMed]

38. Prieto, P.; Pineda, M.; Aguilar, M. Spectrophotometric Quantitation of Antioxidant Capacity through the Formation of a Phosphomolybdenum Complex: Specific Application to the Determination of Vitamin E. Anal. Biochem. 1999, 269, 337-341. [CrossRef] [PubMed]

39. Singh, N.; Rajini, P. Free Radical Scavenging Activity of an Aqueous Extract of Potato. Food Chem. 2004, 85, 611-616. [CrossRef]

40. Clinical and Laboratory Standard Institute, CLSI. M07-A10 Methods for Dilution Antimicrobial Susceptibility Tests for Bacteria That Grow Aerobically; Approved Standard-Tenth Edition; Clinical and Laboratory Standard Institute: Annapolis Junction, MD, USA, 2015.

41. Clinical and Laboratory Standard Institute, CLSI. Antimicrobial and Antifungal Susceptibility Testing Resources. Available online: https://clsi.org/about/about-clsi/about-clsi-antimicrobial-and-antifungal-susceptibility-testing-resources/\# (accessed on 22 September 2021). 